\title{
GMR
}

\section{Heritability of predicted daily enteric methane emissions from growing Nellore cattle}

\author{
T.L.P. Sobrinho', M.E.Z. Mercadante' ${ }^{2}$, R.C. Canesin'2, J.N.S.G. Cyrillo², \\ L.G. Albuquerque ${ }^{1}$ and R.H. Branco ${ }^{2}$ \\ ${ }^{1}$ Faculdade de Ciências Agrárias e Veterinárias, \\ Universidade Estadual Paulista "Júlio de Mesquita Filho", Jaboticabal, SP, Brasil \\ ${ }^{2}$ Centro APTA Bovinos de Corte, Instituto de Zootecnia, Sertãozinho, SP, Brasil \\ Corresponding author: M.E.Z. Mercadante \\ E-mail: mercadante@iz.sp.gov.br / mezmercadante@gmail.com
}

Genet. Mol. Res. 14 (4): 14123-14129 (2015)

Received June 2, 2015

Accepted September 21, 2015

Published October 29, 2015

DOI http://dx.doi.org/10.4238/2015.October.29.33

\begin{abstract}
The objective of this study was to estimate the heritability of predicted daily enteric methane emissions (PME) from growing Nellore cattle. Dry matter intake (DMI) records of 955 Nellore animals that were born between 2004 and 2013, which were obtained in a postweaning performance test lasting $83 \pm 15$ days, were used. The PME of each animal, obtained as $\mathrm{MJ} /$ day and converted to $\mathrm{g} /$ day, was estimated using three equations: $\mathrm{PME}_{1}(\mathrm{MJ} /$ day $)=2.29+0.647 \times \mathrm{DMI}(\mathrm{kg} /$ day $), \mathrm{PME}_{2}(\mathrm{MJ} /$ day $)$ $=3.96+0.561 \times \mathrm{DMI}(\mathrm{kg} /$ day $)$, and $\mathrm{PME}_{3}(\mathrm{MJ} /$ day $)=4.41+0.50 \times \mathrm{DMI}$ (kg/day). The heritability $\left(\mathrm{h}^{2}\right)$ of PME obtained using the three equations was identical to the $h^{2}$ of DMl, regardless of whether the model included the effect of mid-test weight $\left(h^{2}=0.32 \pm 0.069\right)$ or not $\left(h^{2}=0.48 \pm 0.069\right)$. The equations were based exclusively on variations in $\mathrm{DMl}$, and detected variations in this trait without taking into consideration individual differences in enteric methane emission caused by differences in fermentation and digestion capacity. Therefore, prediction equations of enteric methane emission from DMl are not adequate to estimate differences between
\end{abstract}


animals.

Key words: Beef cattle; Prediction equation; Greenhouse gas; Genetic parameter

\section{INTRODUCTION}

The recent accumulation of greenhouse gases in the atmosphere is the main factor in global climate change. FAOSTAT (2013) estimated that emissions from developing countries in 2010 were 1.0 to $1.5 \mathrm{Gt} \mathrm{CO}_{2}$ eq./year. Livestock farming is an important source of greenhouse gases, and generates carbon dioxide $\left(\mathrm{CO}_{2}\right)$, methane $\left(\mathrm{CH}_{4}\right)$, and nitrous oxide $\left(\mathrm{N}_{2} \mathrm{O}\right)$. Enteric $\mathrm{CH}_{4}$ emitted by ruminants is an important greenhouse gas because it is strongly related to global warming, and it accounts for $20 \%$ of all greenhouse gas emissions in Brazil (MCTI, 2013).

Strategies designed to mitigate greenhouse gas emissions have beneficial effects on the efficiency of the production system and on the reduction of global warming. Nutritional plans and diet manipulations aimed at reducing enteric $\mathrm{CH}_{4}$ emissions from ruminants have been extensively studied (Canesin et al., 2014; Cota et al., 2014; Fiorentini et al., 2014). Genetic improvement has been proven to cause small, but cumulative and permanent, changes in cattle performance, and may mitigate $\mathrm{CH}_{4}$ emissions (Herd et al., 2005). Therefore, the genetic variability of traits related to enteric $\mathrm{CH}_{4}$ emission should be quantified, in order to evaluate the suitability of this approach. Improvements in the individual efficiency of feed utilization (Waghorn and Hegarty, 2011), in conjunction with the genetic selection of animals that emit less $\mathrm{CH}_{4}$, could be an option to mitigate the emission of this gas (Pinares-Patiño et al., 2013).

Few studies have reported heritability $\left(\mathrm{h}^{2}\right)$ estimates for $\mathrm{CH}_{4}$ emission in beef cattle (Herd et al., 2014). In British dairy cows, Pickering et al. (2015) obtained $\mathrm{h}^{2}$ estimates of 0.13 and 0.11 for predicteddaily enteric methane emission (PME) and daily dry matter intake (DMI), respectively, and there was a high genetic correlation (0.99) between these traits. However, there are no reports of genetic parameters for traits related to enteric methane emission in Zebu cattle. The objective of the present study was to estimate the heritability of daily PME in growing Nellore cattle.

\section{MATERIAL AND METHODS}

The experiment was conducted at the Centro Avançado de Pesquisa Tecnológica dos Agronegócios (APTA) de Bovinos de Corte, Sertãozinho, an agency of the Instituto de Zootecnia of the State of São Paulo, Brazil. The research center is located in the northern region of the State of São Paulo ( $21^{\circ} 10^{\prime} \mathrm{S}$ latitude and $48^{\circ} 5^{\prime} \mathrm{W}$ longitude), and is characterized by a humid tropical climate with an average annual temperature of $24^{\circ} \mathrm{C}$ and an average annual precipitation of 1312 $\mathrm{mm}$.

DMI and body weight (BW) records of 955 Nellore animals of both sexes that were born between 2004 and 2013 were used. The records were obtained during postweaning performance tests conducted at three facilities equipped with individual pens, or in a collective pen equipped with 10 electronic troughs (GrowSafe ${ }^{\circledR}$ Systems Ltd., Airdrie, Alberta, Canada). Before the performance tests, the animals were acclimatized for 28 days to the diet and facilities. The tests lasted $83 \pm$ 15 days (range, 56-112 days). In 2005, 2006, and 2009, females were divided into two groups that were evaluated in sequence because of a lack of availability of pens. This increased the age 
variation in the database but did not alter the age variation in the group tested. The feed intake of the animals in the individual pens was calculated as the difference between the food offered and the food left over. In the collective pen, daily feed intake data were provided by the GrowSafe ${ }^{\circledR}$ System.

During the years of the test, the diets differed in terms of food composition and the roughage-to-concentrate ratio (\% dry matter), but were isoproteic and isoenergetic $(62 \%$ total digestible nutrients and $13 \%$ crude protein). In 2005 and 2006, the roughage-to-concentrate ratio was 80:20, and corn silage was used as roughage. From 2007 to 2011 , Brachiaria spp hay was used as roughage, and the roughage-to-concentrate ratio was 45:65. In 2012 and 2013, the roughage consisted of corn silage and hay and accounted for $64 \%$ of the diet. In 2014 , the roughage to concentrate ratio $(65: 35)$ and roughage composition were similar.

In the tests performed in the individual pens, the diet was offered twice a day and individually adjusted to result in 5 to $10 \%$ of it being leftover, guaranteeing ad libitum consumption. Individual leftover samples were collected twice a week, combined into one sample after 28 days, and dietary ingredients were collected at 28-day intervals. In the tests performed in the collective pen, the diet offered was adjusted weekly for dry matter content. Samples were frozen and stored for the determination of dry matter.

Samples of dietary ingredients and leftovers were dried at $55^{\circ} \mathrm{C}$ for $72 \mathrm{~h}$ and ground through a 1-mm screen (Willey mill, Arthur Hill, Thomas Co., Philadelphia, PA, USA). Dry matter was determined according to the AOAC (1990, Official Method 934.01). Daily DMI values were excluded from the analysis if there were no leftovers in the individual pens or irregularities were recorded by the GrowSafe system in the collective pen, resulting in a minimum of 49 intake records per animal.

Between 2005 and 2008 (males) and 2009 and 2011 (females), the animals were weighed after a 12-h fast. Between 2009 and 2014, males were weighed without fasting, as were females in 2012. The DMI was obtained as the average of all days of valid feed intake during the test period, and BW was obtained as the mean of the initial and final weights.

The following three equations were used for the daily PME of each animal, obtained as $\mathrm{MJ} /$ day and converted to g/day: $\mathrm{PME}_{1}(\mathrm{MJ} /$ day $)=2.29+0.647 \times \mathrm{DMl}(\mathrm{kg} /$ day) (Ellis et al., 2009), $\mathrm{PME}_{2}(\mathrm{MJ} /$ day $)=3.96+0.561 \times \mathrm{DMI}$ (kg/day) (Ellis et al., 2007, developed using data from a beef cattle database), and $\mathrm{PME}_{3}(\mathrm{MJ} /$ day $)=4.41+0.50 \times \mathrm{DMI}$ (kg/day) (Sobrinho, 2015). These equations were developed for beef cattle, dairy and beef cattle, and Nellore cattle, respectively.

The animals for which records were available were born to 78 sires and 543 dams, and the complete pedigree file up to the 7 th generation included 2288 animals. Contemporary groups were formed according to the year of birth $(1,2, \ldots, 10)$, sex $(1,2)$, and facility $(1, \ldots, 4)$. Variance components for $\mathrm{PME}_{1}, \mathrm{PME}_{2}, \mathrm{PME}_{3}$, and DMI were estimated by the restricted maximum likelihood method in a single-trait animal model using MTDFREML software (Boldman et al., 1995). The following linear mixed models were fitted:

$$
\begin{gathered}
y_{i j k 1}=C_{i}+b_{1}\left(\text { age }_{j}-\overline{\text { age }}\right)+\alpha_{\mathrm{k}}+\varepsilon_{i j k 1} \\
y_{i j k 1}=C_{i}+b_{1}\left(\text { age }_{j}-\overline{\text { age }}\right)+b_{2}\left(b w_{j}-\overline{b w}\right)+\alpha_{k}+\varepsilon_{i j k 1}
\end{gathered}
$$

where $y_{\mathrm{ijkl}}$ is each observation of $\mathrm{PME}_{1}, \mathrm{PME}_{2}, \mathrm{PME}_{3}$, or $\mathrm{DMI} ; \mathrm{CG}_{\mathrm{i}}$ is the fixed effect of the $i^{\text {th }}$ contemporary group $(i=1, \ldots, 21) ; b_{1}$ is the linear regression coefficient of PME on mid-test age; $a^{a g e} e_{j}$ is the age of animal $j ; b_{2}$ is the linear regression coefficient of PME on mid-test weight; $b w_{\mathrm{j}}$ is 
the weight of animal $j$; $\alpha_{i}$ is the random additive genetic effect of animal $I(I=1, \ldots, 2288)$, and $\varepsilon_{\mathrm{ijkl}}$ is the random error associated with each observation.

\section{RESULTS AND DISCUSSION}

Significant differences between mean $\mathrm{PME}_{1}$ (Ellis et al., 2009), mean $\mathrm{PME}_{2}$ (Ellis et al., 2007), and $\mathrm{PME}_{3}$ (Sobrinho, 2015) were observed. The last equation was developed using 48 Nellore animals that were included in the database of the present study, which had records of daily enteric methane emissions obtained using the sulfur hexafluoride tracer gas technique. The three equations used to estimate PME in the present study were based exclusively on the DMI. The latter variable is widely used for this purpose, although the neutral and acid detergent fiber intake, gross and metabolizable energy intake, and roughage-to-concentrate ratio can also be used for predicting enteric methane emissions (Axelsson, 1949; Mills et al., 2003; IPCC, 2006; Ellis et al., 2007, 2009), but are not always available.

The mean PME values were within the range of enteric methane emissions reported in a comprehensive meta-analysis of non-lactating beef cattle fed low-concentrate diets (77.8 to 229.2 g/day) (Ricci et al., 2013). In Nellore cattle, mean daily enteric methane emissions of $147 \mathrm{~g} /$ day have been reported for supplemented corn silage-finished animals at the yearling stage (Fiorentini et al., 2014). Considering the mean PME and gross energy intake (28.83 Mcal/day), losses of gross energy in the form of methane were 5.76 and $6.32 \%$, respectively. These values are slightly lower than that recommended by the IPCC (2006) for young animals in Latin America (6.5\%).

The PME heritability estimate obtained using the three equations was identical to the DMI heritability estimate, regardless of whether Model 1 (without an effect of BW) or Model 2 (including an effect of BW) was used (Table 1). This was expected, because the calculation of PME only took into account DMI.

\begin{tabular}{|c|c|c|c|c|c|}
\hline Trait & Minimum & Maximum & Mean & $\mathrm{h}^{2}$ Model 1 & $\mathrm{~h}^{2}$ Model 2 \\
\hline Mid-test age (day) & 239 & 470 & $329 \pm 37.0$ & & \\
\hline Mid-test body weight $(\mathrm{kg})$ & 125 & 431 & $280 \pm 54.8$ & & \\
\hline $\mathrm{DMI}^{1}$ (kg/day) & 2.16 & 12.6 & $6.83 \pm 1.33$ & $0.47 \pm 0.07$ & $0.32 \pm 0.07$ \\
\hline $\mathrm{PME}_{1}^{2}$ (g/day) & 67.7 & 195 & $125 \pm 16.2$ & $0.47 \pm 0.07$ & $0.32 \pm 0.07$ \\
\hline $\mathrm{PME}_{2}$ (g/day) & 93.8 & 200 & $141 \pm 13.6$ & $0.47 \pm 0.07$ & $0.32 \pm 0.07$ \\
\hline $\mathrm{PME}_{3}$ (g/day) & 94.1 & 189 & $137 \pm 12.1$ & $0.47 \pm 0.07$ & $0.32 \pm 0.07$ \\
\hline
\end{tabular}

'Dry matter intake. ${ }^{2}$ Predicted methane emission, using the following equations: $\mathrm{PME}_{1}(\mathrm{MJ} /$ day $)=2.29+0.647 \times \mathrm{DMl}(\mathrm{kg} /$ day); $\mathrm{PME}_{2}(\mathrm{MJ} /$ day $)=3.96+0.561 \times \mathrm{DMl}(\mathrm{kg} /$ day $) ; \mathrm{PME}_{3}\left(\mathrm{MJ}_{\mathrm{d}}\right.$ day $)=4.41+0.50 \times \mathrm{DMl}(\mathrm{kg} /$ day $)$, all converted to g/day.

Studies that have estimated genetic parameters for PME in dairy cattle have also used prediction equations based exclusively on DMI. Cassandro et al. (2010), using the equation of Ellis et al. (2007) developed from data from dairy cattle employing records of DMI predicted from milk yield, protein percentage, and estimated animal weight, reported a mean PME of $278 \mathrm{~g} /$ day and a heritability of 0.12 . Haas et al. (2011) and Pickering et al. (2015) used a prediction equation based on DMI records obtained during lactation, but included the standard gross energy value of the diet (18.8 MJ/kg DM) and a correction for the level of intake as a multiple of the maintenance intake, based on the IPCC Tier 2 method. Haas et al. (2011) obtained heritabilities of PME ranging 
from 0.29 to 0.42 across lactation, while Pickering et al. (2015) reported estimates of 0.05 to 0.30 . However, the phenotypic or genetic correlation between PME and DMI was 0.99 in both studies.

Using a closed-circuit respirometry system to measure enteric methane emissions from cattle, Herd et al. (2014) reported that the genetic $(0.79 \pm 0.08)$ and phenotypic $(0.65)$ correlations between this trait and DMI were not as high as suggested in studies in which enteric methane emission is predicted by equations, nor was the heritability of enteric methane emission $(0.26 \pm$ $0.08)$ as high as or similar to that estimated for DMI $(0.46 \pm 0.10)$. Furthermore, the heritability of enteric methane emission adjusted for DMI can be considerable (0.13 to 0.18$)$ (Pinares-Patiño et al., 2013; Herd et al., 2014). These results confirm that although the variation in DMI accounts for a very significant fraction of the genetic and phenotypic variability in enteric methane emissions in cattle and sheep, there is a component that is independent of DMI and that offers the opportunity of selection for reduced methane emission (Pinares-Patiño et al., 2013).

Haas et al. (2011) highlighted the limitations of the equation based on the Tier 2 method recommended by the IPCC, which assumes a constant methane emission (6\%) per unit of gross energy intake without taking into consideration differences between animals. Additionally, the little evidence available suggests that an increase in the feed efficiency of animals is partially or completely related to the greater fermentation and digestion of the food consumed, and consequently to a higher methane emission per unit of feed. In Nellore cattle, Magnani et al. (2013) provided evidence of differences in the digestibility of dry matter, neutral and acid detergent fiber, and cellulose between more and less efficient animals.

The objective of the present study was to evaluate the genetic variability of daily enteric methane emissions from growing Nellore cattle, so that this trait may be included in breeding programs. In view of the difficulty and high cost of measuring daily enteric methane emissions from a large number of animals, this variable was estimated using prediction equations. The prediction errors of the equations used in this study were 31,26 , and $17 \%$ of the means for $\mathrm{PME}_{1}, \mathrm{PME}_{2}$, and $\mathrm{PME}_{3}$, respectively (Ellis et al., 2007; Ellis et al., 2009; Sobrinho, 2015). These percentages are fairly high, considering that coefficients of variation of 18 to $20 \%$ have been reported in studies in which enteric methane emission was measured using respirometers or the sulfur hexafluoride tracer gas technique (Herd et al., 2014; Fiorentini et al., 2014; Mercadante et al., 2015). The prediction error itself may limit the detection of individual differences in enteric methane emission. However, the main limitation of the equations used in the present study was that they were based exclusively on the variation in DMI, and therefore could only detect variations in this trait without taking into account individual differences in enteric methane emission because of differences in fermentation and digestion capacity.

Although the prediction equations for enteric methane emission developed from DMI are not adequate to estimate individual differences between animals, they are essential in predicting enteric methane emissions from cattle at farm, national, and international levels. These predictions are a vital part of greenhouse gas calculations that are used for the development of mitigation strategies to reduce these emissions.

In conclusion, prediction equations of enteric methane emission that only use DMI do not detect individual differences between animals.

\section{Conflicts of interest}

The authors declare no conflict of interest. 


\section{ACKNOWLEDGEMENTS}

To Fundação de Amparo à Pesquisa do Estado de São Paulo (FAPESP \#2010/52201-1) and Conselho Nacional de Desenvolvimento Científico e Tecnológico (CNPq \#562783/2010-5) for financial support, and to Coordenação de Aperfeiçoamento de Pessoal de Nível Superior (CAPES) for scholarship.

\section{REFERENCES}

Association of Official Analytical Chemists (AOAC) (1990). Official methods of analysis. 15th ed. AOAC, Arlington, VA

Axelsson J (1949). The amount of produced methane energy in the European metabolic experiments with adult cattle. Ann. $R$. Agric. Coll. Sweden. 16: 404-419.

Boldman KG, Kriese LA, Van Vleck LD, Van Tassel CP, et al. (1995). A manual for use of MTDFREML. A set of programs to obtain estimates of variances and covariances (DRAFT). U.S. Department of Agriculture, Agriculture Research Service, Lincoln, NE.

Canesin RC, Berchielli TT, Messana JD, Baldi F, et al. (2014). Effects of supplementation frequency on the ruminal fermentation and enteric methane production of beef cattle grazing in tropical pastures. Rev. Bras. Zootec. 43: 590-600.

Cassandro M, Cecchinato A, Battagin M and Penasa M (2010). Genetic parameters of predicted methane production in Holstein Friesian cows. Proceedings of the 9th World Congr. Genet. Appl. Livest. Prod., Leipzig. Available at [http://www. kongressband.de/wcgalp2010/assets/pdf/0837.pdf]. Accessed April 16, 2015.

Cota O, Figueiredo DM, Branco RH, Magnani E, et al. (2014). Methane emission by Nellore cattle subjected to different nutritional plans. Trop. Anim. Health Prod. 46: 1229-1234.

Ellis JL, Kebreab K, Odongo NE, Beauchemin K, et al. (2009). Modeling methane production from beef cattle using linear and nonlinear approaches. J. Anim. Sci. 87: 1334-1345.

Ellis JL, Kebreab K, Odongo NE, McBride BW, et al. (2007). Prediction of methane production from dairy and beef cattle. J. Dairy Sci. 90: 3456-3466.

FAOSTAT (Food and Agriculture Organization of the United Nations) (2013). Available at [http://faostat.fao.org/]. Accessed June 30, 2014.

Fiorentini G, Carvalho IPC, Messana JD, Castagnino PS, et al. (2014). Effect of lipid sources with different fatty acid profiles on the intake, performance, and methane emissions of feedlot Nellore steers. J. Anim. Sci. 92: 1613-1620.

Haas Yd, Winding JJ, Calus MPL, Dijkstra J, et al. (2011). Genetic parameters for predicted methane production and potential for reducing enteric emissions through genomic selection. J. Dairy Sci. 94: 6122-6134.

Herd RM, Arthur PF and Archer JA (2005). When pastures limit growth rate of steers those bred for low residual feed intake grow faster. Proc. Assoc. Adv. Anim. Breed. Gen. 16: 330-333.

Herd RM, Arthur PF, Bird SH, Donoghue KA, et al. (2014). Genetic variation for methane traits in beef cattle. Proceedings of the 10th World Congr. Genet. Appl. Livest. Prod., Vancouver. [https://asas.org/docs/default-source/wcgalp-proceedingsoral/038_paper_8845_manuscript_274_0.pdf?sfvrsn=2]. Accessed April 16, 2015.

Intergovernmental Panel on Climate Change (IPCC) (2006). IPCC guidelines for national greenhouse gas inventories. Chapter 10: Emissions from livestock and manure management. Vol. 4: Agriculture, forestry and other land use (Eggleston S, Buendia L, Miwa K, Ngara T, et al., eds.). [www.ipcc-nggip.iges.or.jp/public/2006gl/pdf/4_Volume4/V4_10_Ch10_ Livestock.pdf]. Accessed April 16, 2015.

Magnani E, Nascimento CF, Branco RH, Bonilha SFM, et al. (2013). Relações entre consumo alimentar residual, comportamento ingestivo e digestibilidade em novilhas Nelore. B. Indústr. Anim. 70: 187-194.

Mercadante MEZ, Caliman APM, Canesin RC, Bonilha SFM, et al. (2015). Relationship between residual feed intake and enteric methane emission in Nellore cattle. R. Bras. Zootec. 44: 255-262.

Mills JAN, Kebreab E, Yates CM, Crompton LA, et al. (2003). Alternative approaches to predicting methane emissions from dairy cows. J. Anim. Sci. 81: 3141-3150.

Ministério da Ciência, Tecnologia e Inovação (MCTI) (2013). Estimativas anuais de emissões de gases de efeito estufa no Brasil. Ministério da Ciência, Tecnologia e Inovação, Brasília, MCTI.

Pickering NK, Chagunda MGG, Banos G, Mrode R, et al. (2015). Genetic parameters for predicted methane production and laser methane detector measurements. J. Anim. Sci. 92: 11-20.

Pinares-Patiño CS, Hickey SM, Young EA, Dodds KG, et al. (2013). Heritability estimates of methane emissions from sheep. Animal 7: 316-321. 
Ricci P, Rooke JA, Nevison I and Waterhouse A (2013). Methane emissions from beef and dairy cattle: Quantifying the effect of physiological stage and diet characteristics. J. Anim. Sci. 91: 5379-5389.

Sobrinho TLP (2015). Predição da emissão de metano entérico de bovinos Nelore. Doctoral thesis, Faculdade de Ciências Agrárias e Veterinárias, UNESP, Jaboticabal.

Waghorn GC and Hegarty RS (2011). Lowering ruminant methane emissions through improved feed conversion efficiency. Anim. Feed Sci. Technol. 166-167: 291-301. 